\title{
38. NEOGENE AND PLEISTOCENE OSTRACODES, SITES 959 AND 960, GULF OF GUINEA ${ }^{1}$
}

\author{
Claude Guernet $^{2}$
}

\begin{abstract}
The Neogene from Sites 959 and 960 contains about 20 ostracode species, including Cytherella serratula, Buntonia mackenziei, Bradleya dictyon, Agrenocythere hazelae, Poseidonamicus major, Pseudobosquetina mucronalatum, Legitimocythere acanthoderma, and Henryhowella melobesioides. These species characterize the psychrosphere that was in place in the Gulf of Guinea by at least early Miocene time.
\end{abstract}

\section{INTRODUCTION}

A total of 103 Cenozoic samples from Ocean Drilling Program (ODP) Sites 959, 960, 961, and 962 were examined in this study. All samples were washed over 160- and $80-\mu \mathrm{m}$ sieves, and oven dried at $\leq 65^{\circ} \mathrm{C}$. Samples from the Paleocene through the Holocene from Site 961 , located in $3300 \mathrm{~m}$ water depth (Section 159-961B-4R-3, and 4R-1, and Sections 961A-24R-1, 20R-1, 16R-1, 14R-1, 12R-1, 9R-1, 8R-1, 4R-1, 3R-1, and 1R-1) are devoid of ostracodes, although scattered benthic foraminifers were found. Seven Pliocene to Pleistocene samples from Hole 962B, located in a water depth of $4637 \mathrm{~m}$ (Sections $159-962 \mathrm{~B}-7 \mathrm{H}-3,6 \mathrm{H}-3,5 \mathrm{H}-3,4 \mathrm{H}-3,3 \mathrm{H}-3,2 \mathrm{H}-3$, and $1 \mathrm{H}-3)$, were investigated; calcareous microfossils are generally badly preserved and ostracodes are absent. Only Sites 959 and 960 (respectively, 63 samples from Holes 959A and 959D and 21 samples from Holes 960A and 960C) yielded ostracode, and 19 species belonging to 13 genera have been recorded.

\section{SITE LOCATION}

Site 959 is located $220 \mathrm{~km}$ off the African coast (Fig. 1), in 2100 $m$ water depth on a small plateau that extends just north of the top of the Côte d'Ivoire-Ghana Marginal Ridge, on the southern shoulder of the Deep Ivorian Basin (Mascle, Lohmann, Clift, et al., 1996). Therefore, Site 959 is today isolated from coarse continental sediment and from contamination by neritic ostracodes and foraminifers. Upper Oligocene to Calabrian sediments were recovered in Hole 959A, and Albian to middle Oligocene deposits were recovered in Hole 959D. In the present study (Table 1), only middle Eocene to Pleistocene samples from these holes have been analyzed. The Eocene consists of porcellanite, clay, and micrite and is usually devoid of ostracodes (a single Krithe carapace was found in Core 26R). Likewise, the Oligocene and lower Miocene, consisting of chalky clay with abundant diatoms and radiolarians, are generally without ostracodes (one specimen of Cytherella was collected). Only middle Miocene to Pleistocene nannofossil ooze or clay contains some ostracodes (Table 1).

Site 960 is located 3 miles southeast of Site 959 (Fig. 1), $2050 \mathrm{~m}$ below sea level, on a small plateau that occupies the summit of the Côte d'Ivoire-Ghana Marginal Ridge (Mascle, Lohmann, Clift, et al., 1996). Consequently, as Site 959, it is today isolated from coarse con-

${ }^{1}$ Mascle, J., Lohmann, G.P., and Moullade, M. (Eds.), 1998. Proc. ODP, Sci. Results, 159: College Station, TX (Ocean Drilling Program).

${ }^{2}$ Laboratoire de Micropaléontologie et URA 1761, t. 15, Université Pierre et Marie Curie, F-75252 Paris Cedex 05, France. guernet@ ccr.jussieu.fr tinental sediment and from neritic ostracodes and foraminifers. Turonian or pre-Turonian to Calabrian sediments were recovered in Hole 960A, and only one core was recovered in Hole 960B and that core is Pleistocene in age. Turonian to middle Oligocene deposits were recovered in Hole 960C. In this study, lower Eocene to Pleistocene samples from these holes were analyzed. The lower Eocene consists of palygorskite claystone, and the middle Eocene to lower Miocene of porcellanite and micrite chalk, commonly with radiolarians, whereas the middle Miocene to Pleistocene sediment is comprised of ooze or chalk with clay or micrite. Only the Miocene to Pleistocene samples yielded ostracodes (Tables 2, 3).

\section{SIGNIFICANCE OF THE OSTRACODA}

The Cenozoic ostracodes at Sites 959 and 960 are usually absent or scarce, even where benthic foraminifers are common. Perhaps this infrequency is related to the micritic or clayey nature of the oozes or chalk; the food is too dispersed or too diluted for ostracodes, which are metazoans and relatively mobile compared with foraminifers. Particularly when food is thinly distributed, ostracodes are scattered and the discovery of a sexual partner becomes uncertain.

Despite their overall scarcity in the Miocene to Pleistocene samples of Sites 959 and 960, the following species are present: Cytherella serratula, Buntonia cf. rosenfeldi, Buntonia mackenziei, Bradleya dictyon, Agrenocythere hazelae, Poseidonamicus major, Pseudobosquetina mucronalatum, Legitimocythere acanthoderma, Henryhowella melobesioides, and others (see Tables 1-3; Plates 1$3)$. This fauna characterizes the psychrosphere, which is the water mass beneath the permanent thermocline (Table 4). More precisely, at least since the Miocene, it lies at a depth of about $2000 \mathrm{~m}$ (approximately the upper limit for $P$. mucronalatum, see Benson et al., 1983; Brady, 1880; Dingle and Lord, 1990; Van Harten, 1990). In addition, the Poseidonamicus-Pseudobosquetina-Cytherella serrulata assemblage is characteristic of North Atlantic Deep Water (Dingle and Lord, 1990).

The stratigraphic range of ostracodes from Sites 959 and 960 agrees with the general stratigraphic ranges of the same species in the Atlantic Ocean (Table 5). As off West Africa (ODP Sites 659, 664, and 667, see Guernet and Moullade, 1994), the lack of significant change observed in the composition of assemblages from the Miocene to the Pleistocene reflects the stability of the physical features, principally temperature, of the psychrosphere.

Remark: Three species are probably new, Gen. 1 sp. (Pl. 2, Fig. 8), Gen. 2 sp. (Pl. 3, Fig. 5) and Gen. 3 sp. (Pl. 3, Figs. 6, 7), but fur- 
Figure 1. Locations of ODP Sites 959, 960, 961, and 962. Bathymetry in meters (after Benkhelil et al., 1995).

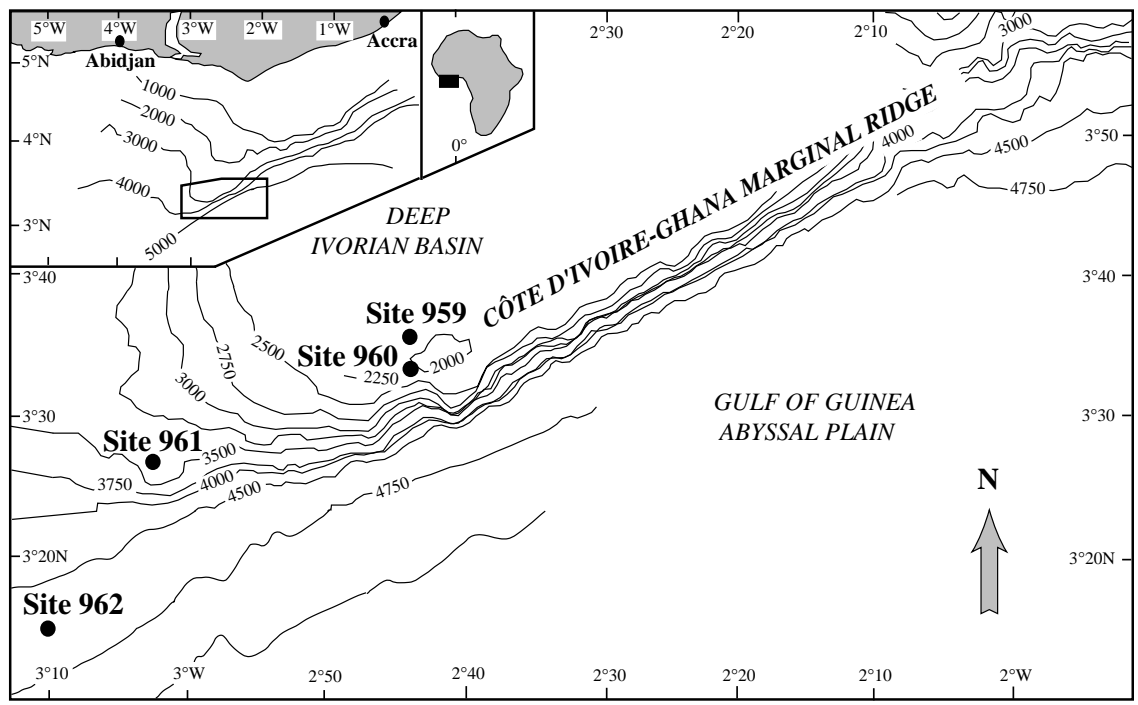

Table 1. Range chart for Cenozoic ostracodes from Holes 959A and 959D.

Table 2. Range chart for Cenozoic ostracodes from Hole 960A.

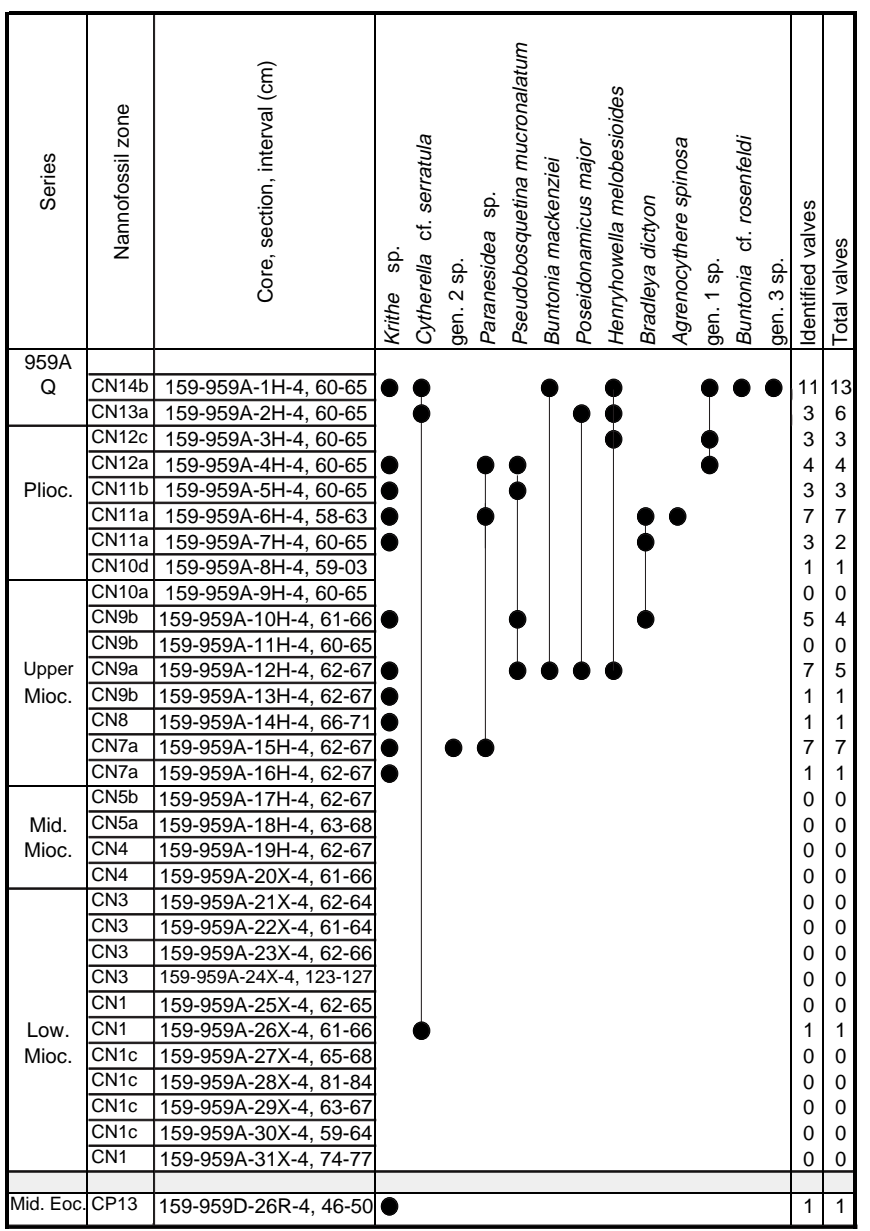

\begin{tabular}{|c|c|c|c|c|}
\hline $\begin{array}{l}\mathscr{D} \\
\stackrel{\mathscr{D}}{\infty} \\
\mathscr{\omega}\end{array}$ & 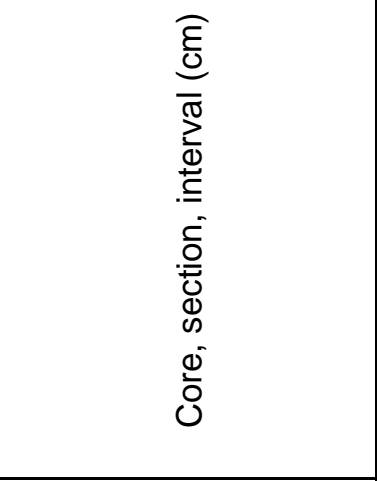 & 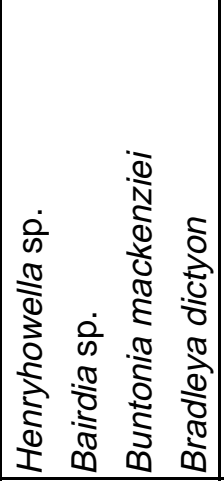 & 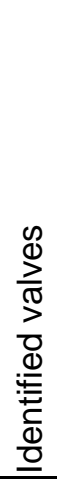 & $\begin{array}{l}\frac{0}{2} \\
\frac{2}{\pi} \\
\frac{2}{\pi} \\
\frac{\pi}{0}\end{array}$ \\
\hline & 159-960A-10R-4; 21-26 & 000 & 3 & 3 \\
\hline Low. & 159-960A-11R-2; 66-69 & & 0 & 0 \\
\hline Mioc. & 159-960A-12R-1; 16-18 & 0 & 1 & 1 \\
\hline & 159-960A-12R-2; 59-63 & & 0 & 0 \\
\hline ? & 159-960A-20R-1; 28-32 & & 0 & 0 \\
\hline ? & 159-960A-21R-1; 17-22 & & 0 & 0 \\
\hline
\end{tabular}

ther investigations are required before they can be formally described.

\section{CONCLUSION}

The limited assemblages of ostracodes do not allow a precise stratigraphic interpretation, but the presence of the same species since the early Miocene shows that the depth of the Côte d'IvoireGhana Marginal Ridge was approximately the same in the Miocene as at the present. Furthermore, the composition of the assemblages suggests that, at least since Miocene time, the cold-water masses overlying the Marginal Ridge originated in the arctic region.

\section{ACKNOWLEDGMENTS}

Thanks to J.-P. Bellier and the other scientists and crew members of Leg 159 of the JOIDES Resolution for recovering the samples that made this study possible. I am greatly indebted to A. Rosenfeld, R. 
Table 3. Range chart for Cenozoic ostracodes from Hole 960C.

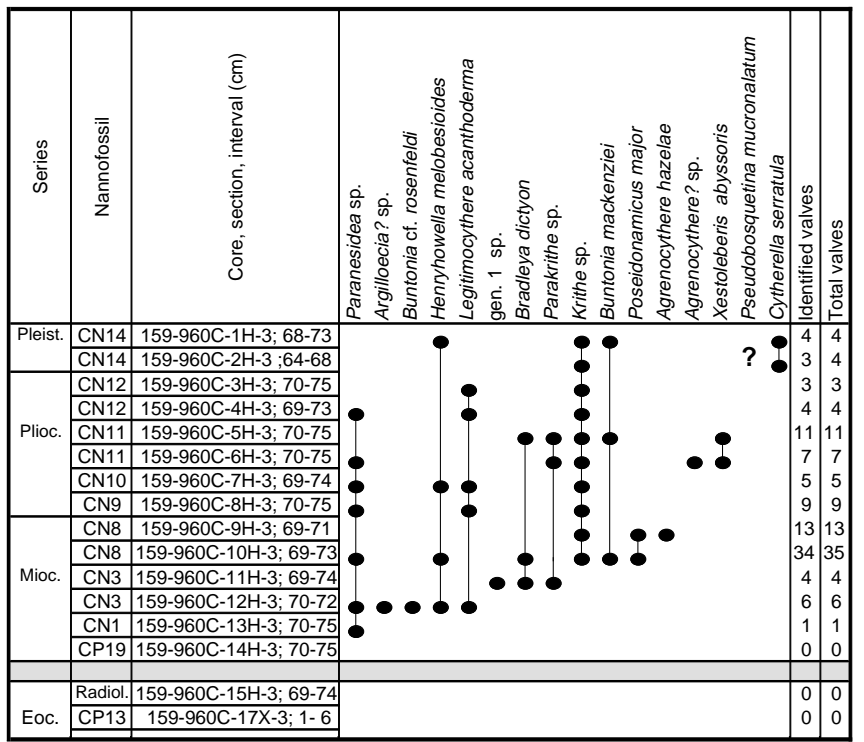

Table 5. Stratigraphic distribution in the Atlantic Ocean of some deepwater ostracodes.

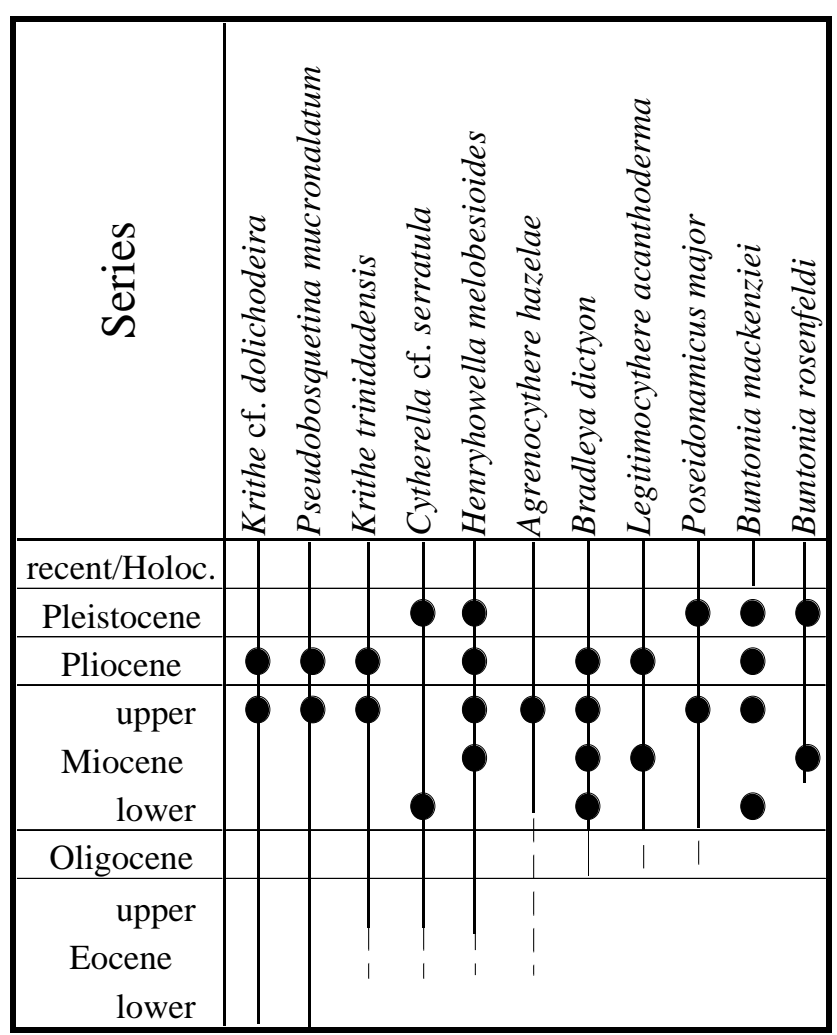

Note: Vertical bars after Bensen (1972, 1977); Benson and Peypouquet (1983); Coles and Whatley (1989); Coles et al. (1990); Cronin and Compton-Goodin (1987); Guernet and Fourcade (1988); Guernet and Moullade (1994); Steineck (1981); Steineck et al. (1984); Whatley (1993); Whatley and Coles $(1987,1991)$ and Whatley and Arias (1993). Solid circles denote occurrence at Sites 959 and 960.
Table 4. Vertical distribution in the Atlantic Ocean of recent ostracode species from Sites 959 and 960.

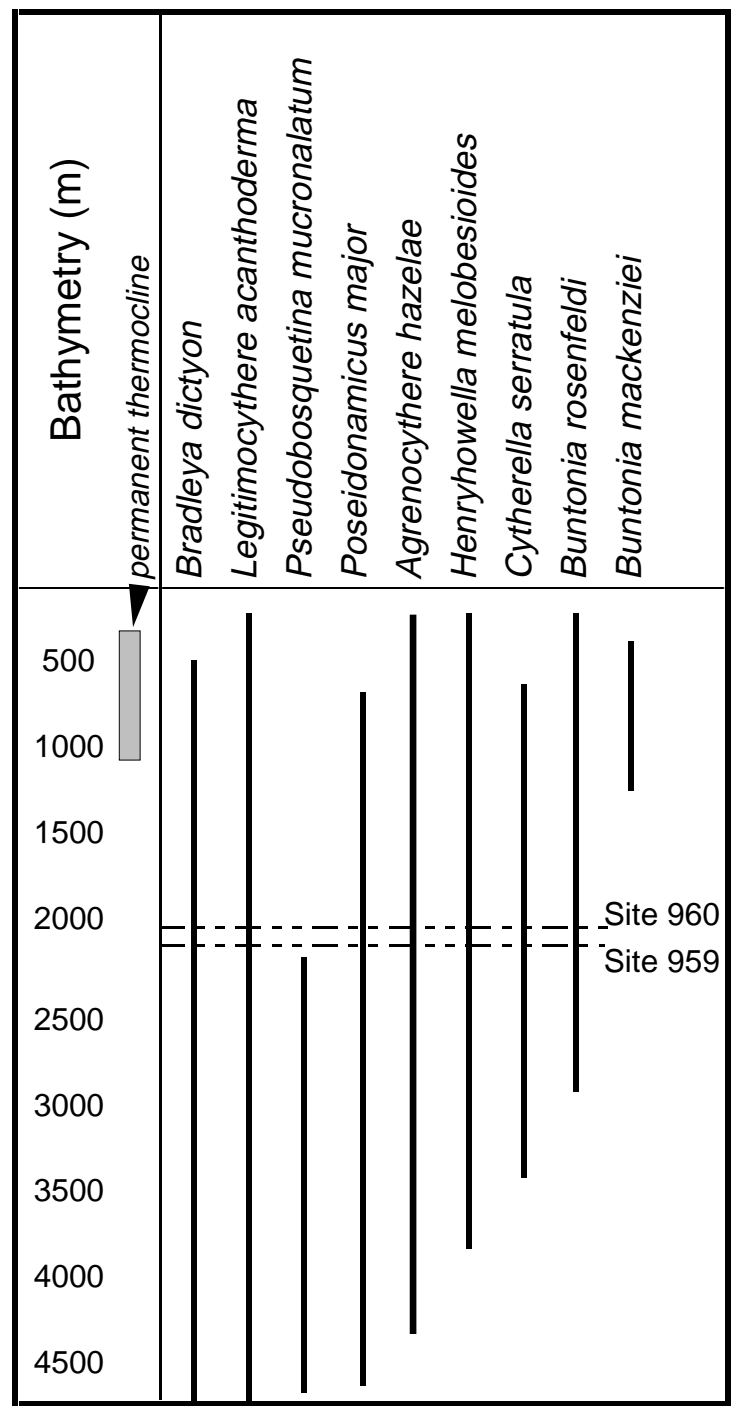

Note: After Bensen, 1972, 1975; Benson et. al., 1983; Brady, 1869, 1880; Cronin, 1984; Dingle et. al., 1990; Malz, 1990; Peypouquet and Benson, 1980; Rosenfeld and Bein, 1978; Van Harten, 1990; Whatley and Coles, 1987.

Whatley, and the staff members of ODP Publications Services for their thoughtful reviews of the manuscript. This study was supported by ODP France.

\section{REFERENCES}

Benkhelil, J., \& l'Équipe Scientifique Embarquée, 1995. ODP Leg 159: la marge transformante de Côte d'Ivoire-Ghana (Atlantique équatorial). Geochronique, 56:8-9.

Benson, R., 1972. The Bradleya problem, with description of two new psychrospheric ostracode genera, Agrenocythere and Poseidonamicus (Ostracoda: Crustacea). Smithsonian Contrib. Paleobiol., 12:1-138. , 1975. The origin of the psychrosphere as recorded in changes of deep-sea ostracode assemblages. Lethaia, 8:69-83.

, 1977. The Cenozoic ostracode faunas of the Sao Paulo Plateau and the Rio Grande Rise (DSDP Leg 39, Sites 356 and 357). In Supko, P.R., Perch-Nielsen, K., et al., Init. Repts. DSDP, 39: Washington (U.S. Govt. Printing Office), 869-883.

Benson, R., Del Grosso, R., and, Steineck, P., 1983. Ostracode distribution and biofacies, Newfoundland continental slope and rise. Micropaleontology, 29:430-453. 
Benson, R., and Peypouquet, J.-P., 1983. The upper and mid-bathyal Cenozoic ostracode faunas of the Rio Grande Rise found on Leg 72 of the Deep Sea Drilling Project. In Barker, P.F., Carslon, R.L., Johnson, D.A., et al., Init.Repts. DSDP, 72: Washington (U.S. Govt. Printing Office) 808-818.

Brady, G., 1869. Quelques entomostracés de Maurice. In De Folin, L., and Perrier, L. (Eds.), Les Fonds de la Mer: Paris (Savy-Libraire Ed.), 1:1316.

1880. Report on the Ostracoda dredged by "H.M.S. Challenger" during the years 1873-1876. Rep. Sci. Res. Voy. Challenger. London, $1: 1-184$.

Coles, G., Ayres, M., and Whatley, R.C., 1990. A comparison of North Atlantic and Pacific Cainozoic deep-sea Ostracoda. In Whatley, R.C., and Maybury, C. (Eds.), Ostracoda and Global Events: London (Chapman and Hall), 287-306

Coles, G., and Whatley, R., 1989. New Paleogene to Miocene genera and species of Ostracoda from DSDP Sites in the North Atlantic. Rev. Esp. Micropaleontol., 21:81-124.

Cronin, T., 1984. Bathyal ostracodes from the Florida-Hatteras slope, the straits of Florida, and the Blake Plateau. Mar. Micropaleontol., 8:89-119.

Cronin, T., and Compton-Goodin, E., 1987. Cenozoic Ostracoda from deep sea drilling project Leg 95 off New Jersey (Sites 612 and 613). In Poag, C.W., Watts A.B., et al., Init. Repts. DSDP, 95: Washington (U.S. Govt. Printing Office), 439-451.

Deltel, B., 1964. Nouveaux ostracodes de l'Eocène et de l'Oligocène de l'Aquitaine méridionale. Actes Soc. Linn. Bordeaux, 100:1-221.

Dingle, R., and Lord, A., 1990. Benthic ostracods and deep water-masses in the Atlantic Ocean. Palaeogeogr. Palaeoeclimatol., Palaeoecol., 80:213235 .

Dingle, R., Lord, A., and Boomer, I., 1990. Deep-water Quaternary Ostracoda from the continental margin off South-Western Africa (SE Atlantic Ocean). Ann. S. Afr. Mus., 99:245-366.

Guernet, C., and Fourcade, E., 1988. Cenozoic ostracodes from Hole 628A, ODP Leg 101, Bahamas. In Austin, J.A., Jr., Schlager, W., et al., Proc. ODP, Sci. Results, 101: College Station, TX (Ocean Drilling Program), $139-151$

Guernet, C., and Moullade, M., 1994. Ostracodes en milieu océanique profond (Atlantique Central) au passage Miocène-Pliocène. Rev. Micropaleontol., 37:257-274.

Malz, H., 1990. Tiefseearten leben länger. Natur Mus., 120:139-152.

Mascle, J., Lohmann, G.P., Clift, P.D., et al., 1996. Proc. ODP, Init. Repts., 159: College Station, TX (Ocean Drilling Program).

Peypouquet, J.-P., and Benson, R., 1980. Les ostracodes actuels des bassins du Cap et d'Angola: distribution bathymétrique en fonction de l'hydrogéologie. Bull. Inst. Geol. Bassin Aquitaine, 28:5-12.

Puri, H., and Hulings, N., 1976. Designation of lectotypes of some ostracods from the Challenger Expedition. Bull. Br. Mus. Nat. Hist. (Zool.), 29:249-315.

Rosenfeld, A., and Bein, A., 1978. A preliminary note on recent ostracodes from shelf to rise sediments off Northwest Africa. Meteor Forschung., C/ 29:4-20.

Steineck, L., 1981. Upper Eocene to Middle Eocene Ostracode fauna and paleo-oceanography of the North Coastal Belt, Jamaica, West Indies. Mar. Micropaleontol., 6:339-366.
Steineck, L., Breen, M., Nevins, N., and O’Harza, P., 1984. Middle Eocene and Oligocene deep-sea Ostracoda from the Oceanic Formation, Barbados. J. Paleontol., 58:1463-1496.

van den Bold, W.A., 1946. Contribution to the study of Ostracoda with special reference to the Tertiary and Cretaceous microfauna of the Caribbean region [Ph.D. thesis]. Utrecht Univ., Amsterdam.

1958. Ostracoda of the Brasso Formation of Trinidad. Micropale ontology, 4:391-418.

Van Harten, D., 1990. Modern abyssal ostracod faunas of the eastern MidAtlantic Ridge area in the North Atlantic and a comparison with the Mediterranean. In Whatley, R., and Maybury, C. (Eds.), Ostracoda and Global Events: London (Chapham and Hall), 321-328.

Whatley, R., 1993. Ostracoda as biostratigraphical indices in Cenozoic deepsea sequences. In Hailwood, E., and Kidd, R. (Eds.), High Resolution Stratigraphy. Geol. Soc. Spec. Publ. London, 70:155-167.

Whatley, R., and Arias, C., 1993. Palaeogene ostracoda from the Tripoli Basin Libya. Rev. Esp. Micropaleontol., 25:125-154.

Whatley, R., and Coles, G., 1987. The late Miocene to Quaternary Ostracoda of Leg 94, Deep Sea Drilling Project. Rev. Esp. Micropaleontol., 19:3397.

1991. Global change and the Biostratigraphy of North Atlantic Cainozoic deep water Ostracoda. J. Micropaleontol., 9:119-132.

Date of initial receipt: 22 July 1996

Date of acceptance: 30 April 1997

Ms 159SR-019

\section{APPENDIX}

Faunal Reference List

Agrenocythere hazelae (van den Bold, 1946), see also Benson (1972)

Agrenocythere spinosa Benson, 1972

Paranesidea sp.

Bradleya dictyon (Brady, 1880), see also Puri and Hulings (1976), Benson (1972), Cronin (1984), and Guernet and Moullade (1994)

Buntonia mackenziei (Puri and Hulings, 1976)

Buntonia rosenfeldi Dingle, Lord and Boomer, 1990

Cytherella cf. consueta Deltel, 1964

Cytherella serratula Brady, 1880 (see also Puri and Hulings, 1976; Whatley and Coles, 1987; Dingle et al., 1990)

Gen. 1 sp.

Gen. 2 sp.

Gen. 3 sp.

Henryhowella melobesioides (Brady, 1869), see also Puri and Hulings (1976) and Dingle et al. (1990)

Krithe cf. dolichodeira van den Bold, 1946 (= ? capensis Dingle et al. (1990)

$K$. cf. trinidadensis van den Bold, 1958. 


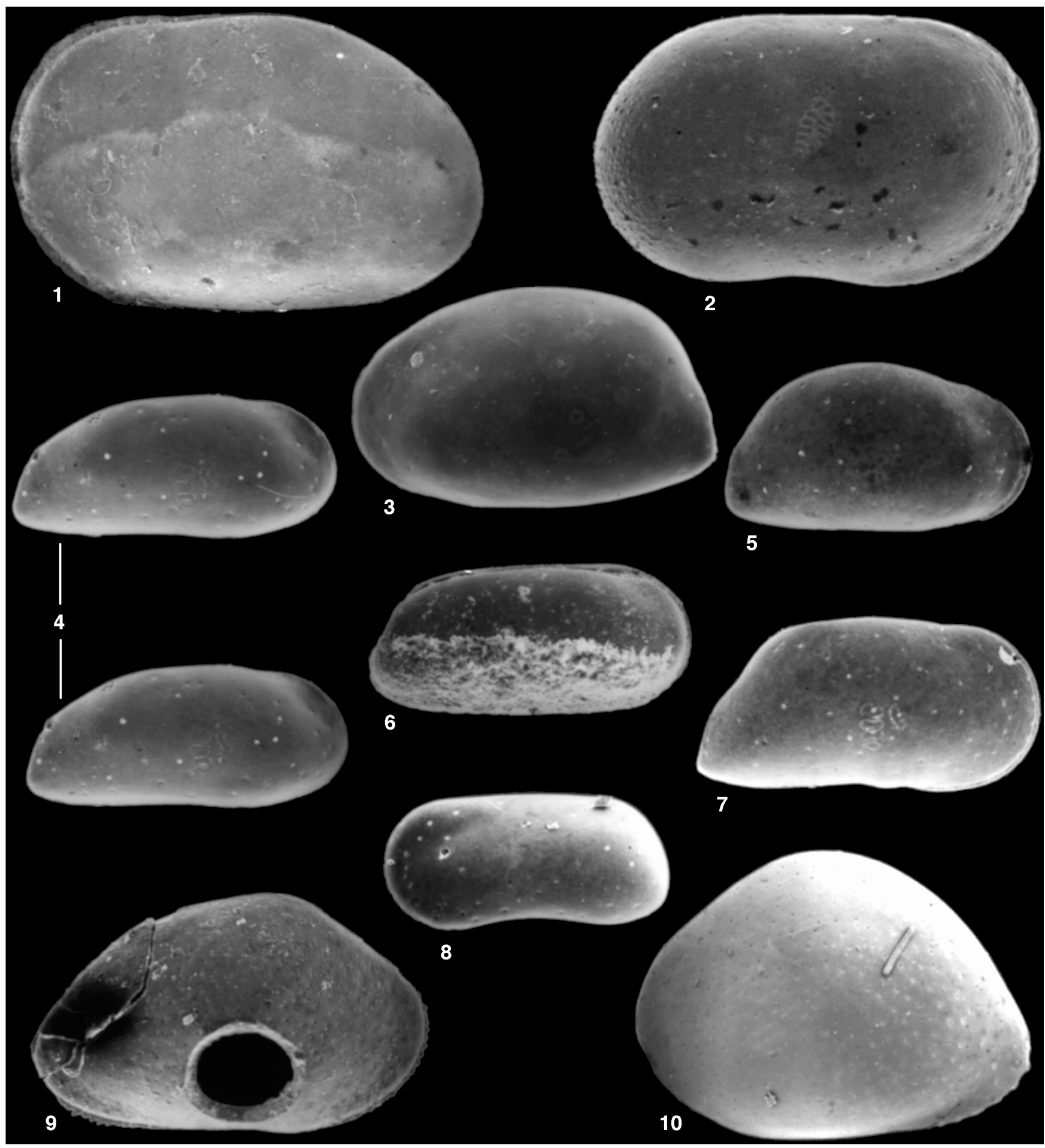

Plate 1. Cenozoic ostracodes of Leg 159. 1. Cytherella cf. consueta Deltel, left valve, 49×, Sample 159-959A-26X-4, 61-66 cm. 2. C. serratula, right valve, 60×, Sample 159-959A-1H-4, 60-65 cm. 3, 4. Krithe cf. trinidadensis, female left valve and male right valve, 50×, Samples 159-961A-4R-1, 60-64 cm, and $159-960 \mathrm{C}-10 \mathrm{H}-3,69-73 \mathrm{~cm}$. 5. $\mathrm{K}$. cf. trinidadensis, 1958 , right valve, female, $52 \times$, Sample 159-960C-5H-3, 70-75 cm. 6. $K$. sp. carapace, right view, 60×, Sample 159-959D-26R-4, 46-50 cm. 7. K. cf. dolichodeira, right valve, 60×, Sample 159-959A-6H-4, 58-63 cm. 8. Parakrithe sp., left valve, 95×, Sample 159-960C-11H-3, 69-74 cm. 9. Paranesidea sp., right valve, 50×, Sample 159-960C-4H-3, 69-73 cm. 10. Paranesidea sp., left valve, 46×, Sample 159-960C$10 \mathrm{H}-3,69-73 \mathrm{~cm}$. 


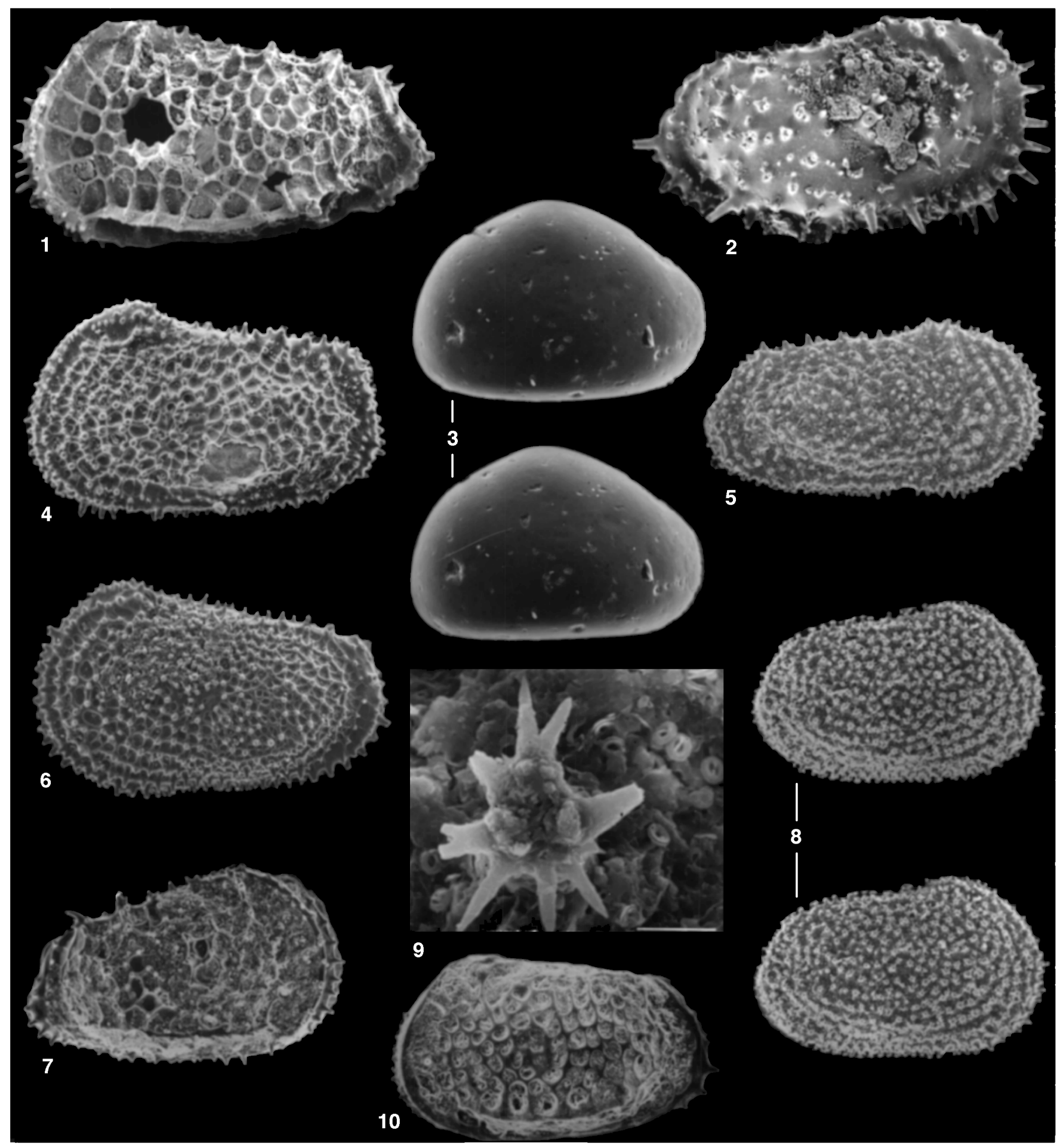

Plate 2. Cenozoic ostracodes of Leg 159. 1. Agrenocythere hazelae, left valve, 50×, Sample 159-960C-9H-3, 69-71 cm. 2. Legitimocythere acanthoderma, right valve, 50×, Sample 159-960C-12H-3, 62-67 cm. 3. Xestoleberis abyssoris, Sample 159-960C-5H-3, 38-40 cm. 4. Henryhowella melobesioides, female left valve, 60×, Sample 159-959A-2H-4, 60-65 cm. 5. H. melobesioides, male right valve, 60×, Sample 159-959A-3H-4, 60-65 cm. 6. H. melobesioides, juvenile left valve, 115×, Sample 159-960A-12R-1, 62-67 cm. 7. Agrenocythere spinosa, right valve, 60×, Sample 159-959A-6H-4, 58-63 cm. 8. Gen. $1 \mathrm{sp} ., 60 \times$, Sample 159-959A-1H-4, 60-65 cm. 9. Gen. 1 sp., same valve as Figure 8, 135×. 10. Poseidoanamicus major, left valve, 50×, Sample 159-959A-12H-3, 62-67 cm. 


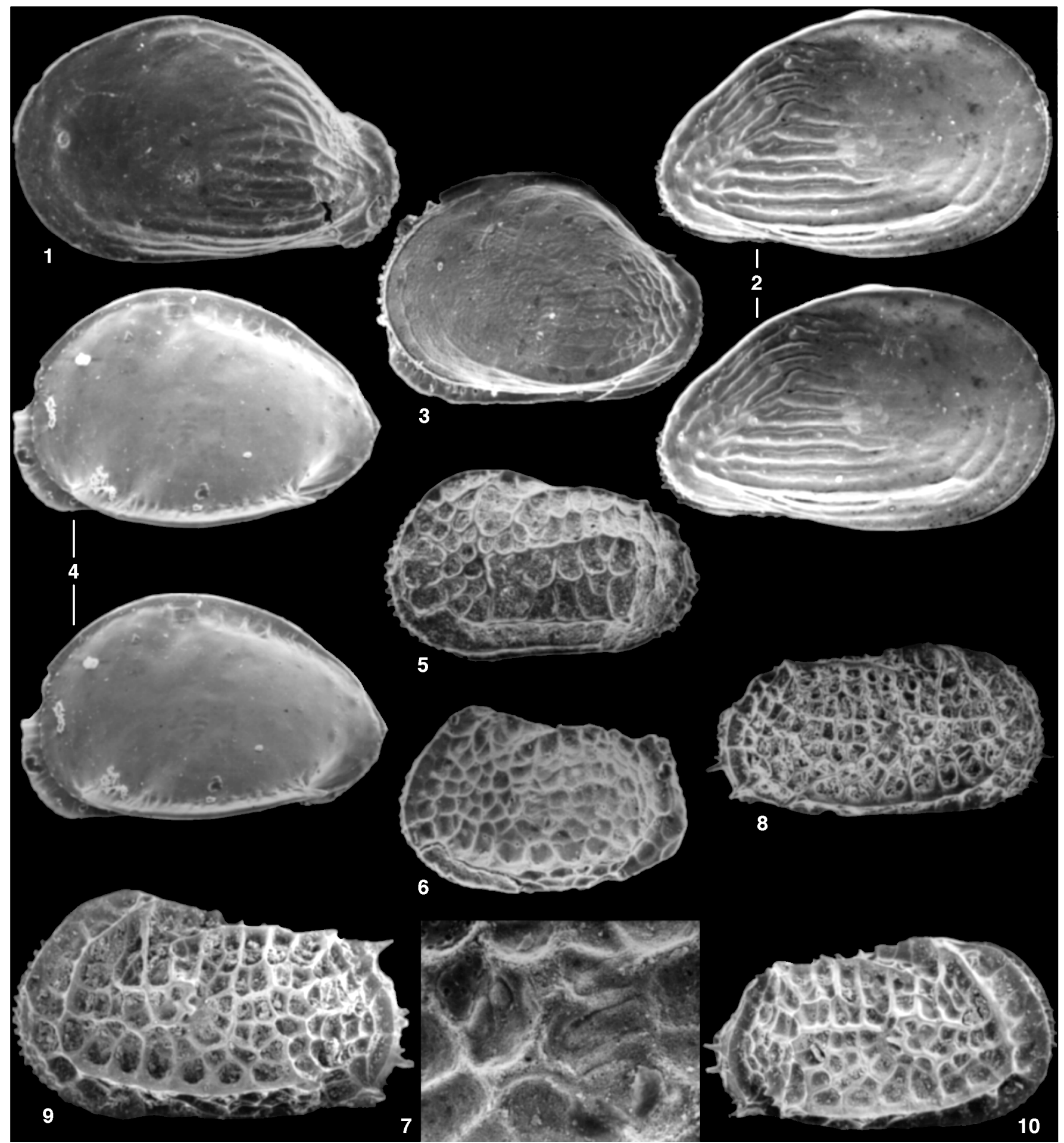

Plate 3. Cenozoic ostracodes of Leg 159. 1, 2. Buntonia mackenziei, left and right valves, 60×, Samples 159-959A-1H-4, 60-65 cm, and 159-960C-1H-4, 60$65 \mathrm{~cm}$. 3. Buntonia $\mathrm{cf}$. rosenfeldi, left valve, $60 \times$, Samples 159-959A-1H-4, 60-65 cm. 4. Pseudobosquetina mucronalatum, left valve, $60 \times$, Sample 159-959A4H-4, 60-65 cm. 5. Gen. 2 sp., left valve, 50×, Samples 159-959A-15H-5, 62-67 cm. 6. Gen. 3 sp., left valve, 60×, Sample 159-959A-1H-4, 60-65 cm. 7. Gen. 3 sp., same valve as Figure 6, muscle scars, $250 \times$. 8-10. Bradleya dictyon, female left and right valves, $52 \times$ and male right valve, 45×, Samples $159-960 \mathrm{C}-11 \mathrm{H}-$ $3,69-74 \mathrm{~cm}, 159-960 \mathrm{~A}-10 \mathrm{R}-4,21-26 \mathrm{~cm}$, and 159-960C-10H-3, 69-73 cm, respectively. 